KEMAS 15 (2) (2019) xxx-xxx
Jurnal Kesehatan Masyarakat

\title{
Variety of Anopheles Mosquito in Salamwates Village, Dongko Subdistrict Trenggalek District, East Java Province
}

\author{
Farah Shabrina Amazida Yuniawan ${ }^{1}$, Budi Utomo², Heny Arwati ${ }^{3 凶}$ \\ ${ }^{1}$ Study program of Medical Doctor, Faculty of Medicine, Universitas Airlangga, Surabaya \\ ${ }^{2}$ Department of Public Health Science, Faculty of Medicine, Universitas Airlangga, Surabaya \\ ${ }^{3}$ Department of Medical Parasitology, Faculty of Medicine, Universitas Airlangga, Surabaya
}

\section{Article Info \\ Article History: \\ Submitted September 2018 \\ Accepted May 2019 \\ Published November 2019 \\ Keywords: \\ Anopheles, suspected \\ malaria vector, \\ Salamwates, Trenggalek \\ DOI \\ https://doi.org/10.15294/ \\ kemas.v15i2.15937}

\section{Introduction}

Malaria is an infectious disease caused by parasite of the genus Plasmodium and transmitted through the bite of Anopheles mosquito. (Arwati et al, 2018). Malaria remains an important health problem in Indonesia (Supriyanto et al, 2017) and also a lifethreatening disease in tropical and subtropical regions (Zareen et al, 2016). Annual parasites incidence (API) is the number of malaria cases per 1000 inhabitants per year. Since 2011, national API has continued to decline and reached 0.85 in 2015. Only the eastern region of Indonesia, such as Papua, Maluku and NTT, still shows a high API (Pusdatin Kemenkes RI, 2016).

East Java is a province where malaria cases are localized in certain regions. The residents of several districts such as Trenggalek, Madiun, Pacitan and Banyuwangi often work outside of Java where malaria is more endemic in order to obtain more income. The number of malaria cases in this province in 2016 was 298 , all of which were imported malaria cases brought by residents returning from working in malaria-endemic areas outside Java and there was no indigenous cases (local infections) (Dinas Kesehatan Jawa Timur, 2017). In Trenggalek District at 2015, the number of microscopically positive malaria cases was 91 (Dinas Kesehatan Kabupaten Trenggalek, 2016) and in 2017 was 105 (Dinas Kesehatan Kabupaten Trenggalek, 2018). There were 26 cases of Imported malaria in the working region of Pandean Primary Health Center (Pandean PHC) or Puskesmas Pandean at 2015, which included Dongko subdistrict, Trenggalek District (Dinas Kesehatan Kabupaten Trenggalek, 2016). The number decreased to 14 cases in 2017 (Dinas Kesehatan Kabupaten Trenggalek, 2018).

Indonesia is home to a variety of malaria vectors, most of which have specific 
bionomic characteristics that have not been characterized. Characterizing the composition of malaria vector species together with the resting behaviour of female mosquitoes, indoor or outdoor, are very important to determine the appropriate method for mosquito capture and for planning of mosquito control program, such as the use of insecticide treated nets (ITN) or indoor residual spray (IRS) (St. Laurent et al, 2017; Basseri et al, 2010).

The prevalence of Anopheles mosquitoes is correlated with the incidence of malaria, while the prevalence of mosquitoes depends on the presence of breeding places in the environment. Thus the existence of breeding places is related to the incidence of malaria (Suwito et al, 2010). In addition, the presence of livestock is also related to the incidence of malaria (Mardiana and Fibrianto, 2009). The existence of livestock can divert Anopheles mosquitoes' human-biting behavior towards livestock, hence reducing malaria transmission to humans or pose a risk of transmitting malaria from mosquitoes that bite both animals and humans (anthropozoophilic) (Donnelly et al, 2015). On the other hand, the anthropophilic nature of Anopheles mosquitoes affects the vector competency of mosquitoes to transmit malaria (Widyastuti et al, 2013).

Female Anopheles mosquitoes bite humans and animals to suck blood as their food source for the development of their eggs. These mosquitoes are actively foraging at night from 18.00 to 06.00 o'clock with different peaks for each species (Munif, 2009). Based on those reasons, Anopheles mosquitoes in Salamwates Village, of Dongko subdistrict, Trenggalek District, East Java Province have been captured and identified to describe the variety in malaria vector in the area. The relationship between captured Anopheles and malaria situation in this village will be discussed further.

Methods

The poposal for this research has been reviewed by the Ethics Committee for Health Research of Faculty of Public Health, Airlangga University as described on the Ethical Approval No. 325-KEPK.

Mosquitoes were caught using Maekawa et al (2009) method using indoor human bait and outdoor cow bait. For human bait trap, two layers of mosquito nets consisting of an inner net measuring $1.2 \times 1.2 \times 2 \mathrm{~m}$ and outer net measuring $3.2 \times 3.2 \times 2 \mathrm{~m}$ were used. For cow bait trap, $4 \times 4 \times 2 \mathrm{~m}$ inner net and a $6 \times 6 \times 2 \mathrm{~m}$ outer net were used. Human volunteer was asked to stay in the inner net and was allowed to do activities freely without leaving the inner net during the capturing time. The cow was tied in the middle of the inner net. Mosquitoes on the outer surface of inner net, and the inner and outer surface of outer nets were collected six times hourly from 18.00 to 24.00 o'clock with 15 minutes interval. The vast majority of Anopheles came to the house around this time (Arwati et al, 2018). Mosquitoes were caught using a mouth-operated aspirator with the aid of a flashlight. Captured mosquitoes caught were placed in the containers and labeled. Identification of mosquito species was carried out in the Department of Medical Parasitology, Faculty of Medicine, Universitas Airlangga using key identification of O'Connor dan Soepanto (1990).

\section{Results and Discussion}

Trenggalek Regency is located in the southern part of East Java province. Trenggalek consists of $2 / 3$ mountainous area, and $1 / 3$ is lowland with an altitude of 0-690 meters above sea level. Trenggalek district is bordered by Pacitan and Ponorogo districts to the west, Ponorogo and Tulungagung districts to the north, Tulungagung district to the east, and the Indonesian sea to the south. Salamwates village is under the working region of Pandean Public Health Center (PHC) or Puskesmas and located on the highest plain in hilly area of Dongko subdistrict, which reaches $848 \mathrm{~m}$ above sea level (Pemerintah Kabupaten Trenggalek, 2016).

In this study, only female mosquitoes were identified, while male mosquitoes was excluded. Seven species were caught by cow bait trap and identified as $A n$. aconitus, $A n$. annularis, An. barbirostris, An. indefinitus, An. kochi, and $A n$. vagus. The results of species identification of Anopheles caught by cow bait trap, number and their distribution based on each collection time are shown in Table 1.

Distribution, frequency and fluctuation of each species were different from each other. Table 1 shows that An. barbirostris was found during every collection time and was the most prevalent at $24(42.11 \%)$ (table 2$)$. The 
Table 1. Distribution of species of Anopheles caught by cow bait trap in Salamwates Village, Dongko Subdistrict, Trenggalek District

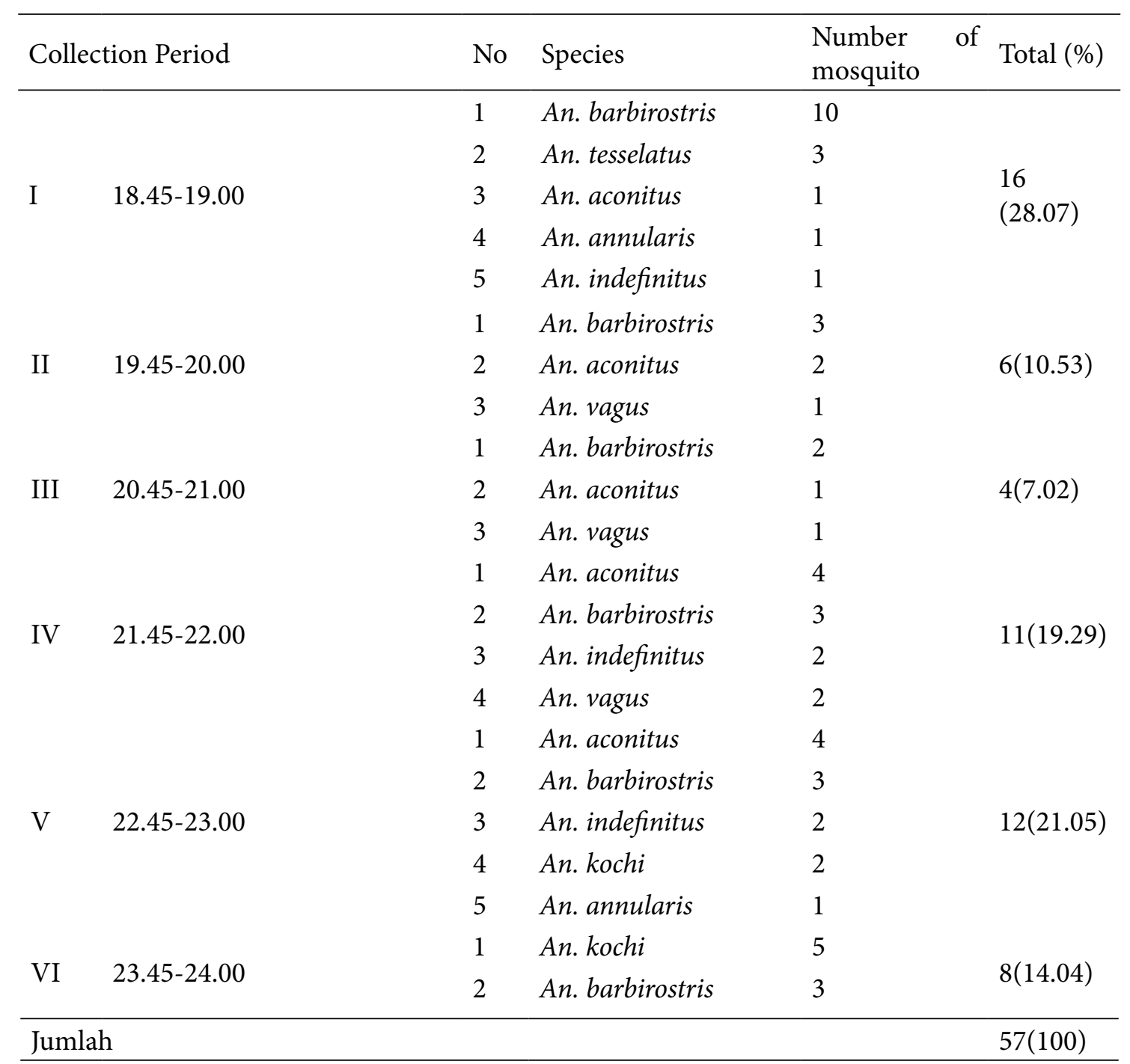

Source: The data were based on the results of species identification of Anopheles mosquitoes caught by cow bait trap in Salamwates village, Donko Subdistrict, Trenggalek District, East Java Province using key identification of O'Connor and Soepanto (1999). The male mosquitoes were not identified.

number of this species at $18.45-19.00$ was 10 mosquitoes, and then decreased along with the late night (Table 2 and Figure 1). The second most prevalent was An. aconitus (12(21.05\%)) which were found around dusk (18.45-19.00) to late night, but disappeared at midnight. Five An. indefinitus (8.77\%) were caught at the first collection time and late night. Two An. annularis (3.51\%) were caught only at 18.45-19.00 and 22.45-23.00. Two species, An. vagus and An. kochi were not found at dusk, but only appeared at night. Interestingly, three mosquitoes of $A n$. tesselatus (5.26\%) only appeared at the first collection time (Table 2 and Figure 1).

Surprisingly, only one An. indefinitus was caught by human bait trap. It was caught at 19.00-19.45, around the peak of night human activity. The villagers usually returned home from various activities, or went to the mosques and retuned home at this time. This species was anthropozoophilic because two An. indefinitus were also caught by cow bait trap at 22.45-23.00.

This study demonstrated that cow bait attracted more mosquitoes than human 
Farah Shabrina Amazida Yuniawan, Budi Utomo, Heny Arwati / Variety of Anopheles mosquito in Salamwates Village

Table 2. Frequency of each Anopheles mosquito species caught by cow bait trap

\begin{tabular}{llll}
\hline Species & $\begin{array}{l}\text { Number } \\
\text { mosquito (\%) }\end{array}$ & Frequency & Collection Period \\
\hline An. barbirostris & $24(42.11)$ & 6 & I, II, III, IV, V, VI \\
An. aconitus & $12(21.05)$ & 5 & I, II, III, IV, V \\
An. indefinitus & $5(8.77)$ & 3 & I, IV, V \\
An. vagus & $7(7.02)$ & 3 & II, III, IV \\
An. annularis & $2(3.51)$ & 2 & I, V \\
An. kochi & $7(12.28)$ & 2 & V, VI \\
An. tesselatus & $3(5.26)$ & 1 & I \\
\hline
\end{tabular}

Source: Number and frequency of mosquito were based on Table 1.

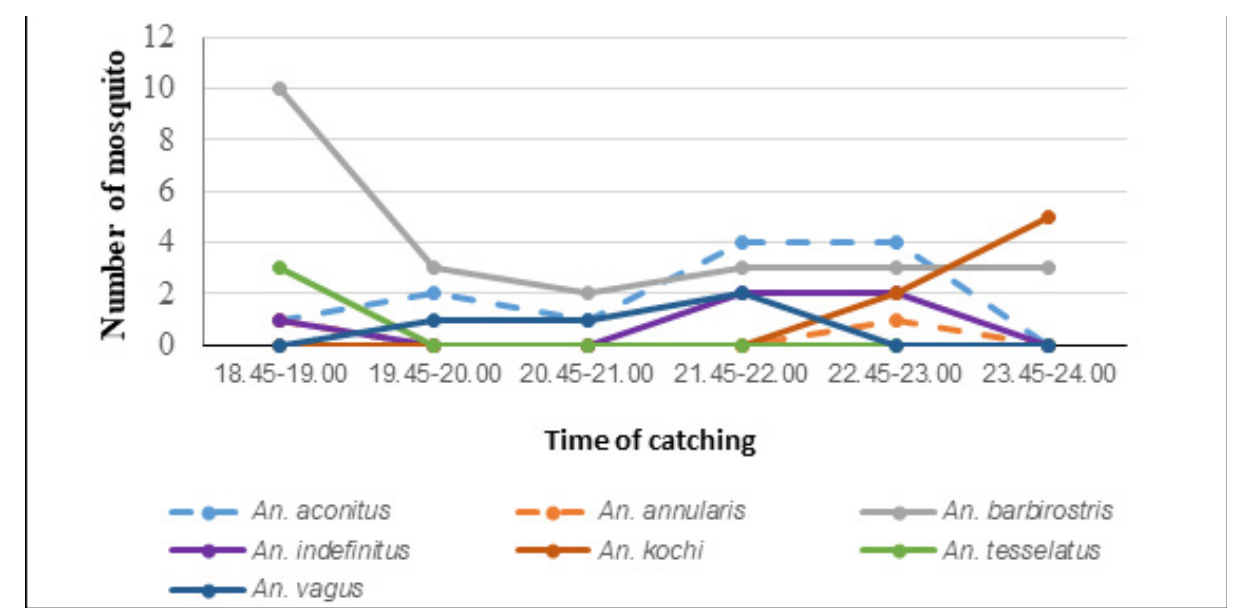

Figure 1.Fluctuation of each Anopheles species caught by Cow Bait Trap based on the collection time

bait and there were more zoophilic Anopheles mosquitoes caught compared to anthropophilic Anopheles. The presence of livestock is related to the incidence of malaria, in addition to the presence of bushes, plantation crops, rice fields, hills and types of breeding places (Mardiana and Fibrianto, 2009). Mosquitoes switched their feeding behaviour to suck animal blood because the villagers were more active indoors at night; therefore, malaria transmission decreased followed by the decreased of malaria cases in this village. In addition, the presence of Anopheles mosquitoes depends also on climate factors that affect the density of mosquitoes in breeding places, such as rainfall, air temperature, water temperature and salinity of breeding places (Tulak et al, 2018).

An. barbirostris and An. Aconitus were two species with the highest frequency found in Salamwates village. This is because $A n$. barbirostris (Noshirma et al, 2012) and An. aconitus (Munif, 2009) are commonly found in mountainous regions. The species of An. kochi, An. indefinitus and An. annularis were found more often in hilly regions, whereas An. vagus and An. tesselatus were found in parts of the lowlands and hilly regions (Ndoen et al, 2010). An. barbirostris is a species that is active from dusk (early night) to late night. As reported by Munif (2009), blood feeding of An. barbirostris occurs throughout the night, with the peak at 23.00-05.00. An. barbirostris is a common malaria vector in Java Island, Indonesia (Ndoen et al, 2010). Likewise, An. aconitus was active from early night to late night, the peak occured at 22.00-23.00 then decreased and increased 
again at 01.00-02.00 (Munif, 2009). In this study, An. aconitus was not found at 24.00.

The lowest frequency of mosquito which caught by using cow bait was $A n$. tesselatus which was only caught once at 18.45 19.00. This species in Central Sumba District, East Nusa Tenggara Province was found only one mosquito around the cow shed at 22.0023.00 (Adnyana, 2011), indicated that this species was active seeking blood at early and late night.

An. annularis was the rarest species, only $2(3.51 \%)$ mosquito to be found in Salamwates village. This species has been incriminated as malaria vector in India, Sri Lanka, Bangladesh, Myanmar, Indonesia, Malaysia and China (Singh et al, 2013).

At 18.45-19.00, four species were found An. aconitus, An. annularis, An. barbirostris, An. tesselatus, and An. indefinitus. The presence of these species might related to the cattle's activities during this time. The existence of livestock such as cattle, buffalo, goats and others can act as malaria zooprophylxasis. By switching mosquitoes to bite animals, transmission of malaria parasites to humans can be prevented (Donnelly et al, 2015). Livestock can have a prophylactic effect where only zoophilic vectors are present and livestock is placed in a way to act as a protective barrier for anopheline mosquitoes (Franco et al., 2014). Conversely, if livestock are placed inside or near the house it can act as a zoopotentiation, mosquitoes that bite animals potentially also bite humans, thereby increasing the risk of malaria transmission (Donnelly et al, 2015). Keeping medium-sized livestock inside and outside the house contributes more to the risk of malaria than its role as zooprophylxasis (Hasyim et al, 2018). The use of cattle, goat and human bait in Saketa village, South Halmahera District, North Maluku Province showed that eight out of nine mosquitoes caught contained sporozoites (St. Laurent et al, 2017). Anopheles mosquitoes that transmit malaria are those containing malaria parasites sporosoite stage in their salivary glands (Mading and Kazwaini, 2014). Indicated that although mosquitoes are zoophilic they can contribute to malaria transmission (St. Laurent et al, 2017) when they turn to zooznthropophilic behaviour. Livestock that is given insecticide treatment and placed far outside the home is one way to reduce malaria cases (Franco et al, 2014). A study showed that using cows covered with insecticides and placed between houses and mosquito breeding places (lagoon) could decrease the density of Anopheles mosquito bites in humans, and reduce the density of mosquitoes caught with the cow bait (Santoso and Ahyanti, 2014).

In this study, Anopheles mosquitoes capture using indoor human bait only resulted in one mosquito identified as An. indefinitus which can act as a malaria vector. This was supported by the discovery of parasites DNA using single step polymerase chain reaction (PCR) method. This species played a role in malaria transmission in the study area because it contained malaria parasites (Arwati et al, 2018). Two mosquitoes of this species were also caught using cow bait at 22.45-23., indicating that An. indefinitus was anthropozoophilic. One An. indefinitus has been also found with outdoor human bait (Nusa and Rohmansyah, 2013), but was not found in Simpang Empat Village, Lenkiti District, Ogan Komering Ulu (OKU), South Sumatra (Mahdalena et al, 2016). The more prevalent zoophilic mosquitoes caught by cow bait than with human bait in the study area, showed that feeding habit of mosquitoes in study area have switched to suck cow blood from human blood. This was related to the decreasing number of malaria cases in Trenggalek District (Trenggalek District Health Office, 2015; 2017). Furthermore, the discovery of asymptomatic malaria (Arwati et al, 2013) and submicrocopic malaria together with $A n$. indefinitus which contains Plasmodium vivax in 2016 showed that local transmission still occurred in Salamwates village where malaria cases were decreased (Arwati et al, 2018). Submicroscopic malaria can disappear spontaneously without treatment within 14 days (Cucunuba et al, 2008).

Provision of prophylactic drugs to residents before traveling to malaria-endemic areas outside Java and the use of repellents while working in those areas are likely to reduce the number of imported malaria cases followed by the disappearance of local transmission.

\section{Conclusion}

There were more Anopheles mosquitoes 
caught by cow bait trap compared to human bait trap in Salamwates Village, Dongko Subdistrict, Trenggalek District. This indicates that the feeding habit of Anopheles mosquitoes has mostly turned to zoophilic, and only a few were anthropozoophilic. This was closely related to the decreased of malaria cases in the study area.

\section{References}

Arwati H, Kusmartisnawati P, Dachlan YP. 2013. Asymptomatic malaria in Trenggalek District, East Java Province as revealed by microscopic examination and single step PCR. Folia Medica Indonesiana. 2013;49:150-154.

Arwati, H., Yotopranoto, S., Rohmah, EA., Safruddin, D. 2018. Submicroscopic malaria cases play role in local transmission in Trenggalek district, East Java Province, Indonesia. Malaria Journal. 17:2-6. Dapat diakses pada https://doi.org/10.1186/s12936-017-2147-7.

Adnyana, I.W.D. 2011. Beberapa Aspek Bionomika Anopheles di Kabupaten Sumba Tengah, Provinsi Nusa Tenggara Timur.Media Litbang Kesehatan, 21(2): 62-70

Basseri, H., Raeisi, A., Khakha, MR., Pakarai, $A$ and Abdolghafar, H. 2010. Seasonal abundance and host-feeding patterns of Anopheline vectors in malaria endemic area of Iran. Journal of Parasitology Research. 2010(2):671291. DOI: 10.1155/2010/671291

Cucunubá ZM, Guerra AP, Rahirant SJ, Rivera JA, Cortés LJ, Nicholls RS. 2008. Asymptomatic Plasmodium spp. infection in Tierralta, Colombia. Mem Inst Oswaldo Cruz;103:66873.

Dinas Kesehatan Propinsi Jawa Timur. 2017. Profil Kesehatan Propinsi Jawa Timur 2016. http:// www.depkes.go.id/resources/download/ profil/PROFIL_KES_PROVINSI_2016/15 Jatim_2016.pdf?opwvc=1. Diakses tanggal10 Agustus 2018.

Dinas Kesehatan Kabupaten Trenggalek. 2016. Profil Kesehatan Kabupaten Trenggalek 2015.http://www.depkes.go.id/ resources/download/profil/PROFIL KAB_KOTA_2015/3503Jatim_Kab_ Trenggalek_2015.pdf. Diakses tanggal10 Agustus 2018.

Dinas Kesehatan Kabupaten Trenggalek. 2018. Profil Kesehatan Kabupaten Trenggalek 2017. http://dkkb.trenggalekkab.go.id/ wp-content/uploads/2018/07/profil-2017depan-belakang.pdf. Diakses tanggal10 Agustus 2018.

Donnelly, B., Berrang-Ford, L., Ross, NA and Miche,
P. 2015. A systematic, realist review

of zooprophylaxis for malaria control. Malar Journal: 14:313. DOI 10.1186/s12936-015-0822-0.

Franco, AO., Gomes, MG., Rowland, M., Coleman, PG and Davies, CR. 2014. Controlling

malaria using livestock-based interventions: a one health approach. PLoS ONE. 014;9:e101699.

Hasyim, H., Dhimal, M., Bauer, J., Montag, D., Groneberg, DA., Kuch, U., and Müller, R. 2018. Does livestock protect from malaria or facilitate malaria prevalence? A cross-sectional study in endemic rural areas of Indonesia. Malar Journal. 17:302. https:// doi.org/10.1186/s12936-018-2447-6.

Maekawa, Y., Sunahara, T., Dachlan, Y.P., Yotopranoto, S., Basuki, S., Uemura, H., Kanbara, H., Takagi, M. 2009. First Record of Anopheles balabacensis from Western Sumbawa Island, Indonesia. Journal of the American Mosquito Control Association, 25(2): 203-205.

Mading, M dan Kazwaini, M. 2014. Ekologi Anopheles spp. di Kabupaten Lombok Tengah. Aspirator. 6(1): 13-20.

Mahdalena, V., Hapsari, N dan Ni'mah, T. 2016. Keragaman jenis dan aktivitas mengisap darah Anopheles spp. di Desa Simpang Empat Kecamatan Lengkiti Ogan Komering Ulu Sumatera Selatan. Aspirator, 8(1), 2016: 9-16.

Mardiana dan Fibrianto, D. 2009. Hubungan karakteristik lingkungan luar rumah dengan kejadian penyakit malaria. KEMAS 5 (1) (2009) 1116.

Munif, A. 2009. Nyamuk Vector Malaria dan Hubungannya dengan Aktivitas Kehidupan Manusia di Indonesia. Aspirator, 1(2): 94102.

Ndoen, E., Wild, C., Dale, P., Sipe, N., Dale, M. 2010. Relationships Between AnophelineMosquitoes and Topography in West Timor and Java, Indonesia. Malaria Journal, pp 1-9.

Noshirma, M., Willa, R.W., Adnyana, N.W.D. 2012. Beberapa Aspek Perilaku Nyamuk Anopheles barbirostris di Kabupaten Sumba Tengah Tahun 2011.Media Litbang Kesehatan, 22(4): 161-166.

O'Connor, CT and Soepanto, A. 1999. Kunci bergambar nyamuk Anopheles dewasa di Indonesia. Departemen Kesehatan Republik Indonesia. Direktorat Jenderal Pemberantasan Penyakit Menular dan Penyehatan Lingkungan Pemukiman

Pusdatin Kementerian Kesehatan RI. 2016. Malaria. Dapat diakses pada: file:///D:/My\%20DATA/ 
Downloads/InfoDatin-Malaria-2016.pdf. Diakses tanggal 5 Juli 2017.

Santoso, B dan Ahyanti, M. 2014. Kombinasi zooprofilaksis dan pembaluran insektisida deltrametrin pada ternak sapi sebagai upaya pengendalian Anopheles. Jurnal Kesehatan, $\mathrm{V}(1)$ : 53-59.

Singh, RK., Haq, S., Gaurav K and Dhiman RC. 2013. Bionomics and Vectorial capacity of Anopheles annularis with special reference to India: A review. J. Commun. Dis. 45(1\&2) $2013: 1-16$

Supriyanto.,Nurhayati, N and Rejeki, DSS. 2017. Analysis of malaria incidence in banyumas using spatiotemporal approach. KEMAS 13 (1) (2017) 1-6.

Suwito., Hadi, UL., Sigit, SH, dan Sukowati, S. 2010. Hubungan iklim, kepadatan nyamuk Anopheles dan kejadian penyakit malaria. J. Entomol. Indon., 7(1): 42-53 42.

St. Laurent, B., Oy, K., Miller, B., Gasteiger, EB., Lee, E., Sovannaroth, S., Gwadz, RW., Anderson, JM and Fairhurst, RM. 2016. Cow-baited tents are highly effective in sampling diverse Anopheles malaria vectors in Cambodia. Malar J. 15:440. DOI 10.1186/s12936-

St. Laurent, B., Burton, TA., Zubaidah, S., Miller, HC., Asih, PB., Baharuddin, A., Kosasih, S., Shinta., Firman, S., Hawley, WA., Burkot, TR., Syafruddin, D., Sukowati, S., Collins, FH and Lobo, NF. 2017. Host attraction and biting behaviour of Anopheles mosquitoes in South Halmahera, Indonesia. Malar J. 16:310 DOI 10.1186/s12936-017-1950-5.

Tulak, N., Handoko, Hidayati, R., Hadi, UK., dan Hakim, L. 2018. Effect of climatic factors and habitat characteristics on Anopheles larval density. KEMAS 13 (3) (2018) 345-355

Zareen, S., Rehman, HU., Gul, N., Zareen, H., Hisham, M., Ullah, I., Rehman, MU., Bibi, S., Bakht, A., Khan J and Saeed, K. 2016. Malaria is still a life threatening disease. Review. Journal of Entomology and Zoology Studies; 4(5): 105-112. 